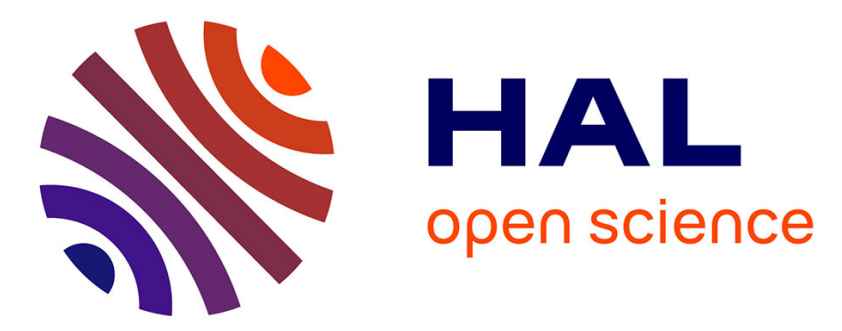

\title{
Soil DNA evidence for altered microbial diversity after long-term application of municipal wastewater
}

Yassine Hidri, Lamia Bouziri, Pierre-Alain Maron, Makram Anane, Naceur Jedidi, Abdennaceur Hassan, Lionel Ranjard

\section{- To cite this version:}

Yassine Hidri, Lamia Bouziri, Pierre-Alain Maron, Makram Anane, Naceur Jedidi, et al.. Soil DNA evidence for altered microbial diversity after long-term application of municipal wastewater. Agronomy for Sustainable Development, 2010, 30 (2), pp.423-431. 10.1051/agro/2009038 . hal-00886540

\section{HAL Id: hal-00886540 \\ https://hal.science/hal-00886540}

Submitted on 1 Jan 2010

HAL is a multi-disciplinary open access archive for the deposit and dissemination of scientific research documents, whether they are published or not. The documents may come from teaching and research institutions in France or abroad, or from public or private research centers.
L'archive ouverte pluridisciplinaire HAL, est destinée au dépôt et à la diffusion de documents scientifiques de niveau recherche, publiés ou non, émanant des établissements d'enseignement et de recherche français ou étrangers, des laboratoires publics ou privés. 


\title{
Soil DNA evidence for altered microbial diversity after long-term application of municipal wastewater
}

\author{
Yassine HIDRI ${ }^{1}$, Lamia BOUZIRI ${ }^{1}$, Pierre-Alain MARON ${ }^{2}$, Makram ANANE $^{1}$, Naceur JEDIDI ${ }^{1}$, \\ Abdennaceur HASSAN ${ }^{1}$, Lionel RANJARD ${ }^{2 *}$ \\ ${ }^{1}$ Centre de Recherches et de Technologies des Eaux, Laboratoire Traitement et Recyclage des Eaux, LP 95, 2050, Hammam-Lif, Tunisia \\ ${ }^{2}$ UMR Microbiologie du Sol et de l'Environnement - INRA, Université de Bourgogne - CMSE, BP 86510, 17 rue de Sully, 21065 Dijon Cedex, France
}

(Accepted 25 September 2009)

\begin{abstract}
Water resources constitute a social, agricultural and economic problem in most countries of the southern Mediterranean Basin. Alternative strategies have been developed such as the reuse of municipal wastewater for irrigation in agriculture. Despite numerous advantages for soil fertility and crop productivity, recycling wastewater in soils also has several ecotoxicological and sanitary problems. Few investigations have assessed the risk by evaluating the impact of wastewater irrigation on soil microbes. Here, we report for the first time the short- and long-term effects of treated municipal wastewater irrigation on the density and genetic structure of bacterial and fungal soil communities. Soils from agricultural sites in Tunisia that had been irrigated with wastewater for 4, 8, 16 and 26 years were characterised. Soil physicochemical and microbial characteristics were assessed by sampling at 0-20 and 20-40 cm depth at each site. Quantitative changes in bacterial and fungal communities were measured by indirect counts on synthetic culture media and qualitative modifications were evaluated by using molecular ecology methods: B- and F-ARISA for Bacterial and Fungal Automated Ribosomal Intergenic Spacer Analysis, respectively. These methods allowed genotyping the structure of bacterial and fungal communities from soil DNA extracts. Our results revealed a significant increase in microbial densities related to the duration of irrigation with wastewater. In addition, wastewater irrigation led to changes in the genetic structure of bacterial and fungal communities, the magnitude and specificity of these changes being significantly correlated with the duration of such irrigation. These results show that wastewater management schemes have a major effect on indigenous microbial abundance and composition in soils that could be related to the recurrent inputs of organic compounds and mineral/metallic elements. In an agro-ecological context, irrigation with municipal wastewater represents an impacting practice that now needs to be evaluated more fully in terms of ecosystem services for sustainable agriculture.
\end{abstract}

\section{INTRODUCTION}

The scarcity of conventional water resources constitutes a social, agricultural and economic problem in most countries of the southern Mediterranean Basin. Water shortage in these countries results from a combination of arid climatic conditions and an increase in water requirements due to population growth and the development of tourism. There is thus an urgent need to make alternative water sources available for agriculture to replace the high quality water required for human consumption (Angelakis et al., 1999). In this context, the use of municipal wastewater for irrigation could provide a realistic alternative water supply for agriculture, as has been demonstrated in many countries in the Mediterranean region, such as Cyprus, Jordan and Tunisia (Angelakis et al., 1999).

The reuse of wastewater mainly for irrigation in agriculture has resulted from advantages related to nutrient recovery, socio-economic implications, reduced fertiliser applications and improved effluent disposal (Candela et al., 2007). The quality criteria generally applied to water for reuse in agriculture have mainly been based on physicochemical and sanitary aspects, focusing on (i) the presence of metallic and organic pollutants, (ii) the existence of potential pathogens (viruses, bacteria and protozoa), (WHO, 1989), and (iii) salinity aspects (Martinez-Beltran, 1999). Treated urban wastewater may contain humic substances, heavy metals, pesticides, by-products of disinfection, industrial contaminants, microorganisms, inorganic and organic compounds, and Pharmaceuticals and Personal Care Products - PPCPs. For many of these, the geochemical and ecotoxicological behaviour is unknown (Doughton, 2004). Some of these are only partially removed by conventional wastewater treatments and may remain in the treated water, affecting its final quality and reuse (Ternes et al., 2002).

* Corresponding author: ranjard@ dijon.inra.fr 
Research studies into the potential chemical and biological contamination of soil by irrigation with wastewater has focused on the ecotoxicological and sanitary effects of reused domestic treated wastewater on the edibility of crops (Crook, 1991; Cooper, 1991; Haas, 1996). The presence of pathogenic microorganisms and $\mathrm{NO}_{2}$ and $\mathrm{CO}_{2}$ production in perched aquifers has been investigated (Ronen, 1996; Campos, 1998) and the possible risk of leaching of pesticide applications on golf courses (Toshinari et al., 1998; Cohen et al., 1999). A modelling of global human risk assessment of organic contaminants (chloroform and pyrene) in reclaimed wastewater used for irrigation was carried out by Weber et al. (2006) and the effect of wastewater irrigation on soil and plant quality parameters has been described by Dère et al. (2006).

Although microorganisms are the most ubiquitous, diverse and abundant living organisms in soil, and despite their key role in a wide range of biogeochemical cycles with agronomic consequences on soil fertility, functioning and buffering of pollutants, few studies have investigated the ecological impact of irrigation with wastewater on soil communities. In addition, most of the research conducted on wastewater reuse in agriculture has been focused on its short- and mediumterm effects (Palese et al., 2009) on plant growth and development with little attention paid to the soil impact following long-term irrigation with treated wastewater. In this context, the aim of our study was to evaluate the long- and shortterm effects of treated wastewater irrigation, of 4 to 26 years' duration, on the abundance and genetic structure of the soil microbial communities. Experiments were conducted in the "Nabeul-Hammamet" region of northern Tunisia. This is one of the most drought-stressed countries in the Middle Eastern and North African region, with freshwater per capita of around $450 \mathrm{~m}^{3} /$ year. Treated wastewater currently represents approximately $5 \%$ of Tunisia's total available water but is expected to increase to $11 \%$ by 2030 (Shetty, 2004). The reuse of treated wastewater in irrigation is considered as a strategic approach to preserve freshwater resources in this region and has been practised since 1980 .

We compared the microbial abundance and genetic structure of indigenous bacterial and fungal communities in soils that had been irrigated with wastewater for $4,8,16$ or 26 years, in the same experimental field. The bacterial and fungal abundance in each location was assessed from counts on synthetic culture media. The genetic structures of the bacterial and fungal communities, indigenous to the soils irrigated for different durations, were assessed by ARISA (automated ribosomal intergenic spacer analysis), a DNA "fingerprinting" approach.

\section{MATERIALS AND METHODS}

\subsection{Study area and sampling strategy}

The Nabeul valley (northeast Tunisia) has been irrigated since 1980. The climate is temperate and semi-arid with mild, wet winters. The mean monthly temperature ranges from 12 to $27{ }^{\circ} \mathrm{C}$. Evapotranspiration $(10.3 \mathrm{~mm} / \mathrm{d})$ has been recorded in July and August, whereas rainfall mainly occurs from
September to March. Annual precipitation is around $470 \mathrm{~mm}$. Irrigation is based on flooding through furrows. The mean annual application rates vary between 1500 and $2200 \mathrm{~mm}$ depending on the crop. The mean insolation is between 5.4 and $12.9 \mathrm{~h} /$ day.

Soils were sampled at four different sites, all under an orange grove that had been irrigated for different lengths of time: "el Haouria"site: Soils irrigated with wastewater for the last 4 years.

"Messadi"site: Soils irrigated with wastewater for the last 8 years.

"Beni Khiar" site: Soils irrigated with wastewater for the last 16 years.

"Souhil" site: Soils irrigated with wastewater for the last 26 years.

Sampling plots were separated by about 4 to $5 \mathrm{~km}$. Sampling was carried out with a drill at the end of the dry season between September 22nd and 24th 2006 in a representative plot of about 0.5 ha size on each site. Each plot was divided into three locations or blocks, and in each block four soil cores were sampled and were then pooled for further analysis. The soil was sieved $(2 \mathrm{~mm})$, placed inside vented plastic bags and stored at $5{ }^{\circ} \mathrm{C}$ for 15 days for later analysis. Physicochemical soil characteristics were measured in each site for each treatment by the Laboratory of Soil Analysis (INRA-Arras, France, http://www.arras.inra.fr/), using standard methods. The main results are given in Table I.

\subsection{Wastewater characteristics}

This study was conducted at the SE4 Wastewater Treatment Plant (Nabeul, northeast Tunisia), which was set up in May 1979. The $\mathrm{SE}_{4}$ wastewater treatment plant is an activated sludge-extended aeration system that involves a mechanical screen, grit removal tanks, primary sedimentation tanks, extended aeration tanks, and finally, sedimentation tanks. The characteristics of the wastewater used for irrigation varied both within and between the years of application. The wastewater was, on average, alkaline with a basic $\mathrm{pH}$ value of 7.6 and had a moderate level of total dissolved solids (TDS) of $1556 \mathrm{mg} . \mathrm{L}^{-1}$. It contained considerable amounts of nitrate (31 mg. $\left.\mathrm{L}^{-1}\right)$, ammonia $\left(53 \mathrm{mg} . \mathrm{L}^{-1}\right)$, phosphate $\left(17.8 \mathrm{mg} . \mathrm{L}^{-1}\right)$ and potassium (53.3 mg. $\left.\mathrm{L}^{-1}\right)$, which are considered essential nutrients for improving plant growth together with soil fertility and productivity levels. It presented an electrical conductivity of $3.27\left(\mathrm{mmhos} . \mathrm{cm}^{-1}\right)$, and a chemical and biochemical oxygen demand of 95 and $17.4 \mathrm{mg} . \mathrm{L}^{-1}$, respectively.

On the other hand, the concentrations of micronutrients and heavy metals in the wastewater were relatively low, with $0.0007 \mathrm{mg} . \mathrm{l}^{-1}$ of Cd, 0.02 of $\mathrm{Co}, 0.01$ of $\mathrm{Cu}, 0.05$ of $\mathrm{Mn}, 0.19$ of Fe, 0.05 of Ni, 0.03 of $\mathrm{Pb}, 0.03$ of $\mathrm{Zn}$ and 0.03 of Cr. These concentrations met the standards for wastewater reuse irrigation of Tunisian and F.A.O. norms. This wastewater could thus be considered of good quality. Given the fact that such metals could accumulate in the soil and plants following continuous use of wastewater in irrigation, their periodic monitoring 
Table I. Soil physicochemical properties of the different sites.

\begin{tabular}{|c|c|c|c|c|c|c|c|c|c|c|}
\hline Sites & $\begin{array}{l}\text { Depth } \\
(\mathrm{cm})\end{array}$ & $\begin{array}{c}\text { Clay } \\
\%\end{array}$ & $\begin{array}{c}\text { Silt } \\
\%\end{array}$ & $\begin{array}{c}\text { Sand } \\
\%\end{array}$ & $\mathrm{pH}$ & $\begin{array}{c}\mathrm{C}_{\mathrm{org}} \\
\mathrm{mg} / \mathrm{g}^{-1} \\
\text { soil }\end{array}$ & $\begin{array}{c}\mathrm{N}_{\text {org }} \\
\mathrm{mg} / \mathrm{g}^{-1} \\
\text { soil }\end{array}$ & $\mathrm{C} / \mathrm{N}$ & $\begin{array}{c}\text { CEC } \\
\mathrm{Cmol}^{+} . \mathrm{kg}^{-1} \\
\text { soil }\end{array}$ & $\begin{array}{c}\mathrm{CaCO}_{3} \\
\mathrm{mg} / \mathrm{g}^{-1} \\
\text { soil }\end{array}$ \\
\hline \multirow[t]{2}{*}{ El Haouria } & $0-20$ & 7.5 & 4.1 & 88.1 & $\begin{array}{l}7.91^{\mathrm{a}} \\
( \pm 0.4)\end{array}$ & $\begin{array}{c}8.6^{\mathrm{b}} \\
( \pm 0.9)\end{array}$ & $\begin{array}{c}0.81^{\mathrm{b}} \\
( \pm 0.9)\end{array}$ & 10.61 & $\begin{array}{c}4.73^{\mathrm{a}} \\
( \pm 0.5)\end{array}$ & $\begin{array}{c}2.8^{\mathrm{a}} \\
( \pm 0.3)\end{array}$ \\
\hline & $20-40$ & 8.7 & 4.8 & 86.3 & $\begin{array}{c}8.4^{\mathrm{a}} \\
( \pm 0.2)\end{array}$ & $\begin{array}{c}4^{\mathrm{a}} \\
( \pm 0.5)\end{array}$ & $\begin{array}{c}0.39^{\mathrm{a}} \\
( \pm 0.5)\end{array}$ & 10.25 & $\begin{array}{c}4.2^{\mathrm{a}} \\
( \pm 0.4)\end{array}$ & $\begin{array}{c}1.6^{\mathrm{a}} \\
( \pm 0.1)\end{array}$ \\
\hline \multirow[t]{2}{*}{ Messadi } & $0-20$ & 15.3 & 10.1 & 72.9 & $\begin{array}{c}8.52^{\mathrm{a}} \\
( \pm 0.3)\end{array}$ & $\begin{array}{c}10.1^{\mathrm{b}} \\
( \pm 1.2)\end{array}$ & $\begin{array}{l}0.854^{\mathrm{b}} \\
( \pm 0.9)\end{array}$ & 11.82 & $\begin{array}{c}7.09^{\mathrm{b}} \\
( \pm 0.9)\end{array}$ & $\begin{array}{c}16.7^{\mathrm{c}} \\
( \pm 3.1)\end{array}$ \\
\hline & $20-40$ & 18.6 & 11.8 & 67.6 & $\begin{array}{c}8.58^{\mathrm{a}} \\
( \pm 0.3)\end{array}$ & $\begin{array}{c}9.9^{\mathrm{b}} \\
( \pm 0.8)\end{array}$ & $\begin{array}{l}0.684^{b} \\
( \pm 0.7)\end{array}$ & 14.47 & $\begin{array}{c}8.09^{\mathrm{b}} \\
( \pm 0.7)\end{array}$ & $\begin{array}{c}19.8^{\mathrm{c}} \\
( \pm 2.5)\end{array}$ \\
\hline \multirow[t]{2}{*}{ Beni Khiar } & $0-20$ & 8.3 & 8.6 & 72.5 & $\begin{array}{c}8.42^{\mathrm{a}} \\
( \pm 0.3)\end{array}$ & $\begin{array}{c}24.4^{\mathrm{c}} \\
( \pm 1.6)\end{array}$ & $\begin{array}{c}1.1^{\mathrm{c}} \\
( \pm 1.5)\end{array}$ & 22.18 & $\begin{array}{c}5.46^{\mathrm{a}} \\
( \pm 0.5)\end{array}$ & $\begin{array}{c}10.5^{\mathrm{b}} \\
( \pm 1.5)\end{array}$ \\
\hline & $20-40$ & 9.0 & 9.0 & 71.9 & $\begin{array}{c}8.52^{\mathrm{a}} \\
( \pm 0.2)\end{array}$ & $\begin{array}{c}22.2 \\
( \pm 1.2)\end{array}$ & $\begin{array}{c}1^{\mathrm{c}} \\
( \pm 0.9)\end{array}$ & 22.2 & $\begin{array}{c}5.48^{\mathrm{a}} \\
( \pm 0.5)\end{array}$ & $\begin{array}{c}9.9^{\mathrm{b}} \\
( \pm 1.1)\end{array}$ \\
\hline \multirow[t]{2}{*}{ Souhil } & $0-20$ & 10.9 & 8.1 & 80.1 & $\begin{array}{c}8.23^{\mathrm{a}} \\
( \pm 0.3)\end{array}$ & $\begin{array}{c}11^{\mathrm{b}} \\
( \pm 1.5)\end{array}$ & $\begin{array}{l}0.95^{\mathrm{b}, \mathrm{c}} \\
( \pm 0.8)\end{array}$ & 11.6 & $\begin{array}{l}6.14^{\mathrm{a}, \mathrm{b}} \\
( \pm 0.6)\end{array}$ & $\begin{array}{c}9.3^{\mathrm{b}} \\
( \pm 0.9)\end{array}$ \\
\hline & $20-40$ & 11.7 & 8.5 & 78.7 & $\begin{array}{l}8.47^{\mathrm{a}} \\
( \pm 0.4)\end{array}$ & $\begin{array}{c}7.7^{\mathrm{b}} \\
( \pm 0.8)\end{array}$ & $\begin{array}{c}0.65^{\mathrm{b}} \\
( \pm 0.7)\end{array}$ & 11.85 & $\begin{array}{l}5.64^{\mathrm{a}} \\
( \pm 0.5)\end{array}$ & $\begin{array}{c}11.3^{\mathrm{b}} \\
( \pm 1.2)\end{array}$ \\
\hline
\end{tabular}

(a, b, c): for each property, means followed by the same letter are not significantly different according to the Fisher LSD test at $P<0.05$. Each value is the mean of 3 replicates.

should be an important component of wastewater management.

\subsection{Microbial enumeration}

Bacteria and fungi were extracted by blending soil samples with $0.8 \%$ (w/v) sterile $\mathrm{NaCl}$ solution and the homogenous soil suspension was serially diluted ten-fold in sterile saline solution. Indirect counting of bacteria was carried out by spreading $100 \mu \mathrm{L}$ of appropriate dilutions on plate count agar (aerobic plate count agar) (Al-Lahham et al., 2003; Ranjard et al., 1997). Bacterial colonies were counted after $48 \mathrm{~h}$ of incubation at $28{ }^{\circ} \mathrm{C}$. Only plates with between 10 and 100 colonies per plate were counted. For fungi, the appropriate soil dilution was spread on malt extract agar (30 g. $\mathrm{L}^{-1}$ malt extract, 3 g. $\mathrm{L}^{-1}$ proteose peptone, $1.5 \%$ agar, $\mathrm{pH}$ 5.6). The number of developing colonies was counted after 7 days of incubation at room temperature and was expressed as the number of colonyforming units (CFU) per gram of soil.

\subsection{Soil DNA extraction}

Microbial DNA was extracted from independent triplicates of soils sampled in each site, according to the method described by Ranjard et al. (2003). Briefly, $1 \mathrm{~g}$ from each soil sample was mixed with $4 \mathrm{~mL}$ of a solution containing $100 \mathrm{mM}$ Tris (pH 8.0), $100 \mathrm{mM}$ EDTA (pH 8.0), $100 \mathrm{mM} \mathrm{NaCl}$ and 2\% (wt/vol) sodium dodecyl sulphate. Two g of 106- $\mu$ m-diameter glass beads and 8 glass beads of $2 \mathrm{~mm}$ diameter were added to the mixture in a bead-beater tube. The samples were then homogenised for $30 \mathrm{~s}$ at $1600 \mathrm{rpm}$ in a mini bead-beater cell disruptor (Mikro-dismembrator, S. B. Braun Biotech International). The samples were incubated for $20 \mathrm{~min}$ at $70{ }^{\circ} \mathrm{C}$, then centrifuged at $14000 \times g$ for $1 \mathrm{~min}$ at $4{ }^{\circ} \mathrm{C}$. The collected supernatants were incubated for $10 \mathrm{~min}$ on ice with $1 / 10$ volume of $3 \mathrm{M}$ potassium acetate $(\mathrm{pH}$ 5.5) and centrifuged at $14000 \times g$ for $5 \mathrm{~min}$. After precipitation with one volume of ice-cold isopropanol, the nucleic acids were washed with $70 \%$ ethanol. DNA was separated from the residual impurities, particularly humic substances, by centrifuging through two types of minicolumns. Aliquots $(100 \mu \mathrm{L})$ of crude DNA extract were loaded onto polyvinyl polypyrrolidone minicolumns (BIORAD, Marne-la-Coquette, France) and centrifuged at $1000 \times g$ for $2 \mathrm{~min}$ at $10^{\circ} \mathrm{C}$. The collected elute was then purified with the Geneclean turbo kit (Q-Biogene, Illkirch, France).

\subsection{Automated RISA fingerprinting}

The genetic structure of the microbial communities was determined by automated ribosomal intergenic spacer analysis (ARISA), which exploits the variability in length of the intergenic spacer (IGS) between small (16S for bacteria and $18 \mathrm{~S}$ for fungi) and large (23S for bacteria and $28 \mathrm{~S}$ for fungi) subunit rRNA genes in the rrn operon.

The bacterial and fungal ribosomal IGS were amplified with the primers S-D-Bact-1522-b-S-20/L-D-Bact-132-a-A18 and ITS1F/3126T, respectively, with PCR conditions as 
described by Ranjard et al. (2003). Fifty nanograms of DNA were used as a template in PCR. A fluorescent-labelled primer was used for the LiCor ${ }^{\circledR}$ DNA sequencer (ScienceTec, Les Ulis, France) in B-ARISA and F-ARISA, namely the IRD800 dye fluorochrome (MWG SA Biotech, Ebersberg, Germany). PCRs were performed using the S-D-Bact-1522-b-S-20 and 3126T primers labelled at their 5' end with the IRD800 fluorochrome. The concentration of labelled PCR products was estimated, and between 0.5 and $1 \mu \mathrm{L}$ of the product was added to deionised formamide and denatured at $90{ }^{\circ} \mathrm{C}$ for $2 \mathrm{~min}$. ARISA fragments were resolved on $3.7 \%$ polyacrylamide gels and run under denaturing conditions for $15 \mathrm{~h}$ at $3000 \mathrm{~V} / 60 \mathrm{~W}$ on a LiCor $^{\circledR}$ DNA sequencer (ScienceTec). The data were analysed using the 1D-Scan software (ScienceTec). This software converted fluorescence data into electrophoregrams in which the peaks represented the PCR fragments. The heights of the peaks were calculated together with the median filter option and the Gaussian integration in 1D-Scan, and represented the relative proportion of fragments in the total products. Lengths (in base pairs) were calculated by using a standard size with bands ranging from 200 to $1206 \mathrm{bp}$.

\subsection{Statistical analysis}

The effect of irrigation on soil physicochemical properties and microbial abundance was tested by one-way ANOVA and differences between means were tested with the Fisher LSD test. ARISA data obtained from the 1D-Scan software were converted into a table summarising the band presence (i.e., peak) and intensity (i.e. height or area of peak) using the PrepRISA program (Ranjard et al., 2003). This software enabled us to choose the number of peaks (i.e. all detected populations vs. the most dominant populations), the profile resolution (between $1 \mathrm{bp}$ and $10 \mathrm{bp}$ ), and the method of evaluating peak intensity (area). As described in a previous study, we used 100 peaks, a 2 bp resolution and the Gaussian peak area for a robust analysis of bacterial and fungal communities (Ranjard et al., 2003). The B- and F-ARISA covariance matrices, microbial communities as rows and bands as columns, were subjected to Principal Component Analysis (PCA), which provided an ordination of bacterial or fungal communities in a factorial map based on the scores of the first two principal components. PCA was performed using the ADE-4 software (Thioulouse et al., 1997).

\section{RESULTS AND DISCUSSION}

Water shortage in the semi-arid region of Nabeul (North Tunisia) has led to the development of irrigation of agricultural soils with municipal wastewater. We focused our study on the environmental evaluation of this practice in order to describe its impact on the soil microbial component in terms of quantitative and qualitative modifications. To evaluate the chronic soil contamination and cumulative impact of wastewater we compared different sites with irrigations of different lengths of time (from 4 to 26 years).

\subsection{Impact of irrigation with wastewater on soil physicochemical properties}

No significant variations in soil texture and $\mathrm{pH}$ were observed between soils originating from the different sites, except for the El Haouria soil which exhibited a lower $\mathrm{pH}$ (Tab. I). This absence of significant variations in soil properties between the plots validated the choice of the experimental sites in Nabeul by demonstrating the absence of plot-to-plot soil heterogeneity that might have masked the impact of irrigation management. However, other soil parameters, such as soil structure and porosity, were not tested in our study and might have been affected by such practices (Bronick and Lal, 2005).

The lower $\mathrm{pH}$ and carbonate contents observed at the El Haouria site could be partly explained by the fewer years of irrigation and therefore lower impact of the wastewater. Indeed, the wastewater used was alkaline with a $\mathrm{pH}$ of 7.8, which is in agreement with the FAO guidelines for effluent quality for irrigation (Candela et al., 2007). Recurrent use of this wastewater could have increased the soil $\mathrm{pH}$ in sites irrigated for more than 8 years. Schipper et al. (1996) found that soil $\mathrm{pH}$ increased following long-term wastewater irrigation and attributed this to the chemistry and high contents in the wastewater of basic cations such as $\mathrm{Na}, \mathrm{Ca}$ and $\mathrm{Mg}$, which accumulate in such soils (see Sect. 2.2). Other authors found that soil $\mathrm{pH}$ decreased with wastewater irrigation due to the oxidation of organic compounds and nitrification of ammonium (Mazahreh, 2003). Similarly, the soil calcareous level $\left(\mathrm{CaCO}_{3}\right.$, $\mathrm{g} / \mathrm{kg}$ ) ranged from 9.3 to 11.3 in the field irrigated for 26 years and from 2.83 to $1.6 \%$ in the field irrigated for 4 years. This implied that the soil calcareous level increased significantly after 26 years of wastewater irrigation.

Significantly higher $\mathrm{C}_{\text {org }}$ and $\mathrm{N}_{\text {org }}$ contents were detected at both depths $(0-20 \mathrm{~cm}$ and $20-40 \mathrm{~cm})$ in the Beni Khiar (BK) soil. These modifications in soil organic status led to an increase in the $\mathrm{C} / \mathrm{N}$ ratio, which was about 22 compared with 11 for the other soils. Major soil modifications, consecutive to irrigation management, have already been reported in other studies, resulting in increases in $\mathrm{C}_{\text {org }}$ and $\mathrm{N}_{\text {org }}$ contents (Ramirez-Fuentes et al., 2002). In our case, the soil organic C content increased significantly with the increased number of years of wastewater irrigation (Tab. I), except for the Souhil site, and was directly attributed to the input of organic compounds in the wastewater (see Sect. 2.2). Although soil organic carbon contents accumulated more in the topsoil, the significantly higher $\mathrm{C}_{\text {org }}$ contents at the deeper level at the Beni Khiar site showed that the effect of irrigation was not limited to the surface layer, and could be explained by the sandy texture of this soil, leading to a weak discrimination between the soil horizons in depth (Ranjard et Mariez. pers. comm.).

Weak but significant variations in mineral and metallic elements were observed between the soils of the different sites (Tab. II). However, an accumulation of metallic and mineral elements, dependent on the type of irrigation, was highlighted, which was greatest in the topsoil. These results are in agreement with those reported by Mazahreh (2003) and Day et al. (1974), who found higher extractable phosphorus levels in soil 


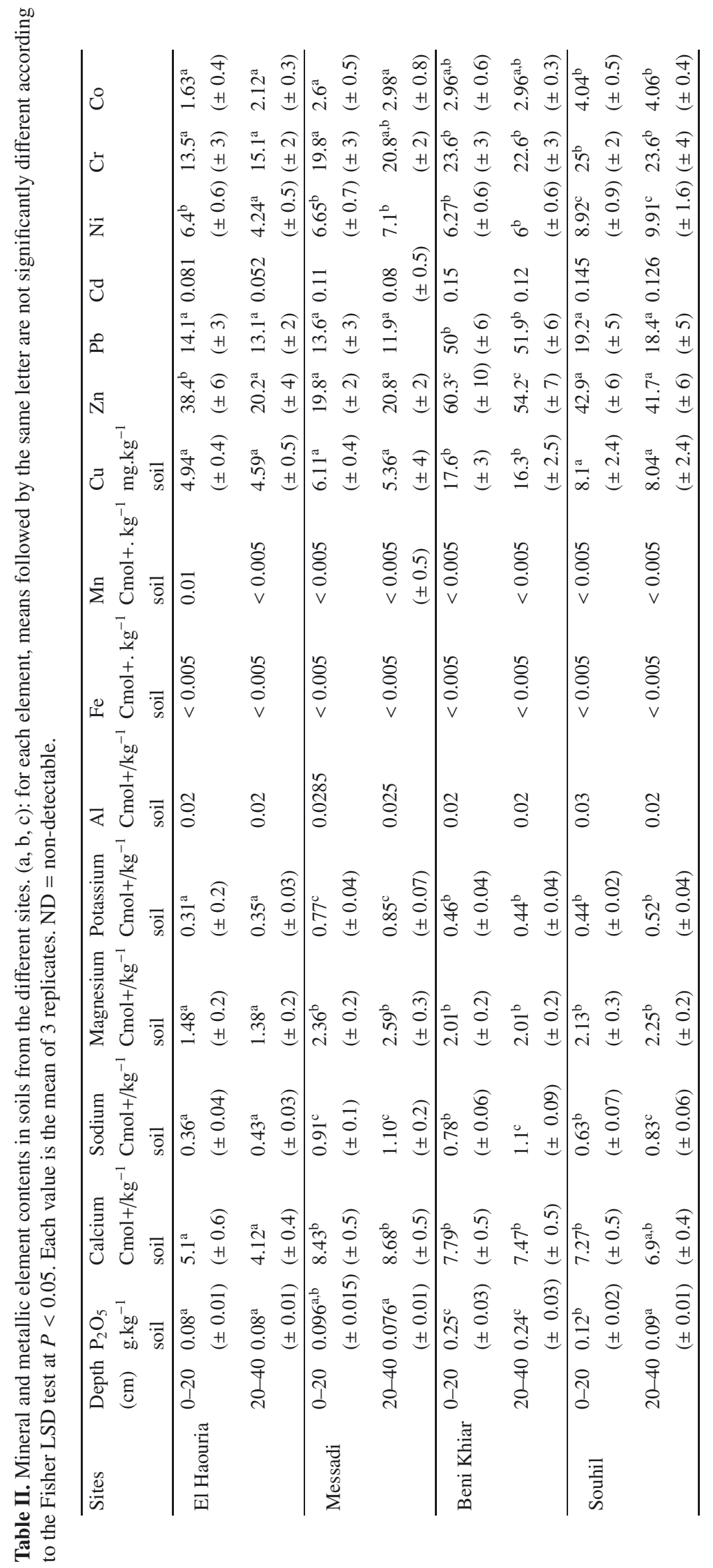


Table III. Bacterial and fungal counts in soils from the studied sites.

\begin{tabular}{cccc}
\hline Sites & $\begin{array}{c}\text { Depth } \\
(\mathrm{cm})\end{array}$ & $\begin{array}{c}\text { Heterotrophic } \\
\text { bacteria } \\
\left(\mathrm{g}^{-1} \text { soil }\right)\end{array}$ & $\begin{array}{c}\text { Filamentous fungi } \\
\left(\mathrm{g}^{-1} \text { soil }\right)\end{array}$ \\
\hline \multirow{2}{*}{ El Haouria } & $0-20$ & $\begin{array}{c}3.5^{\mathrm{a}}( \pm 0.8) \times 10^{5} \\
20-40\end{array}$ & $\begin{array}{c}2.3^{\mathrm{a}}( \pm 0.3) \times 10^{\mathrm{a}}( \pm 1.1) \times 10^{3} \\
2.5^{\mathrm{a}}( \pm 0.8) \times 10^{3}\end{array}$ \\
\hline \multirow{2}{*}{ Messadi } & $0-20$ & $3.5^{\mathrm{a}}( \pm 0.4) \times 10^{5}$ & $1^{\mathrm{a}}( \pm 0.9) \times 10^{3}$ \\
& $20-40$ & $7.9^{\mathrm{a}}( \pm 0.6) \times 10^{4}$ & N.D. \\
\hline \multirow{2}{*}{ Beni Khiar } & $0-20$ & $8.2^{\mathrm{b}}( \pm 1.1) \times 10^{5}$ & $7.1^{\mathrm{b}}( \pm 0.9) \times 10^{3}$ \\
& $20-40$ & $6.4^{\mathrm{b}}( \pm 1) \times 10^{5}$ & $6.05^{\mathrm{b}}( \pm 0.8) \times 10^{3}$ \\
\hline \multirow{2}{*}{ Souhil } & $0-20$ & $9.2^{\mathrm{b}}( \pm 1.2) \times 10^{5}$ & $8.1^{\mathrm{b}}( \pm 1.5) \times 10^{3}$ \\
& $20-40$ & $7.3^{\mathrm{b}}( \pm 1.3) \times 10^{5}$ & $4.06^{\mathrm{a}}( \pm 1.6) \times 10^{3}$ \\
\hline
\end{tabular}

$(a, b)$ : for each count, means followed by the same letter are not significantly different according to the Fisher LSD test at $P<0.05$. Each value is the mean of 3 replicates. ND = non-detectable.

irrigated with wastewater than in soil irrigated with fresh water or rainfall. An accumulation of metallic elements is commonly observed in soils subjected to long-term wastewater irrigation (Lawes, 1993; Siebe, 1995).

In our case, the weak accumulation of metallic elements was probably due to the sandy texture of the soil and the low level of organic matter, leading to weak adsorption of metallic and mineral cations on the matrix (Alloway, 1995). Nevertheless, this weak accumulation did not exclude the possibility of recurrent chemical pollution which could lead to considerable modification of the soil biological component.

\subsection{Impact of irrigation with wastewater on soil microbial abundance}

The microbial density in the different soils of the studied site was evaluated by counting the bacteria and fungi on culture media (Tab. III). The average numbers of bacteria in the topsoil ranged from $3.5( \pm 0.3) \times 10^{5}$ to $9.2( \pm 1.2) \times$ $10^{5}$ CFU.g ${ }^{-1}$ soil and from $7.9( \pm 0.6) \times 10^{4}$ to $7.3( \pm 1.3) \times$ $10^{5}$ at $20-40 \mathrm{~cm}$ depth (Tab. III). Similar significant differences were recorded for fungi, both between the different soils and between the depths studied (Tab. III). Altogether, these data revealed that long-term irrigation with wastewater induced a significant increase in soil microbial abundance. This growth of microorganisms might be explained by the ready source of easily degradable compounds in the oligotrophic soil environment brought about by wastewater irrigation (Ramirez-Fuentes et al., 2002). Indeed, microorganisms are mainly heterotrophic and carbon-limited in soil and the observed differences could be due to a higher availability and quality of the carbon source supplied by wastewater irrigation. The weak significance of the positive relationship $(r=0.35$, $P>0.05$ ) between the increase in $\mathrm{C}_{\text {org }}$ contents and microbial abundance could be partly explained by the sandy texture of the soils, which would promote greater and more rapid organic matter mineralisation. This would lead to a transitory increase in $\mathrm{C}$ with a significant resiliency due to the rapid decrease in the stock of fresh organic matter (Lejon et al., 2007).

Furthermore, the observed stratification of microbial biomass with soil depth generally corresponded to the decrease in $\mathrm{C}_{\text {org }}$ and $\mathrm{N}_{\text {org }}$ contents, as classically observed (Berg et al., 1998; Lejon et al., 2005, 2007). In our case, this positive relationship was corroborated by our results (Tabs. I and III).

Altogether, our results showed that long-term irrigation with wastewater significantly stimulated microbial growth by providing a nutrient source. The accumulation of metallic elements in the soils did not have a significant deleterious impact on microbial density. However, the recorded contents of the different metallic elements did not attain a sufficiently high toxicological level to induce stable modifications in microbial density (Ranjard et al., 2006, 2008; Duxburry and Bicknell, 1983).

\subsection{Impact of irrigation with wastewater on soil microbial genetic structure}

Qualitative modifications of the indigenous bacterial and fungal communities were assessed by applying ARISA fingerprinting directly to soil DNA extracts from the different sites. ARISA fingerprinting allows rapid examination of the genetic structure of complex bacterial and fungal communities and has been demonstrated to be sensitive and relevant for evaluating modifications in community composition in space and time (Ranjard et al., 2003; Lejon et al., 2005).

Visual comparison of the B- and F-ARISA profiles obtained from the soils in the different sites highlighted specific patterns, dependent on the wastewater management scheme, suggesting that each type of irrigation management induced a particular genetic structure of the microbial community (Fig. 1). PCA of the B- and F-ARISA profiles confirmed the impact of the wastewater management practices by discriminating the different sites (Fig. 1). Closer inspection of the PCA of B-ARISA reveals that the indigenous bacterial communities from the topsoil of El Haouria and Messadi were significantly separate from those of sites irrigated for more than 16 years on the PC1 axis (explaining $42 \%$ of the observed variability, Fig. 2). In sites subjected to long-term management, the Souhil and Beni Khiar sites were discriminated on the PC2 axis (explaining $29 \%$ of the observed variability). PCA of the F-ARISA profiles showed similar discrimination patterns (Fig. 2) but with a greater magnitude of modifications on both PC axes between and within recently irrigated sites (4 and 8 years) and those irrigated for longer (16 and 24 years). This implied that the fungal communities seemed to be more sensitive to the type of irrigation management and its recurrence over time. These data are not consistent with those of other studies which demonstrated that soil fungal communities were more stable than soil bacterial communities when subjected to environmental perturbations, due to their higher functional redundancy (de Boer et al., 2005; Lejon et al., 2007).

Altogether, these results suggest that irrigation with wastewater significantly modified the genetic structure of the bacterial and fungal communities and that the magnitude of 
A

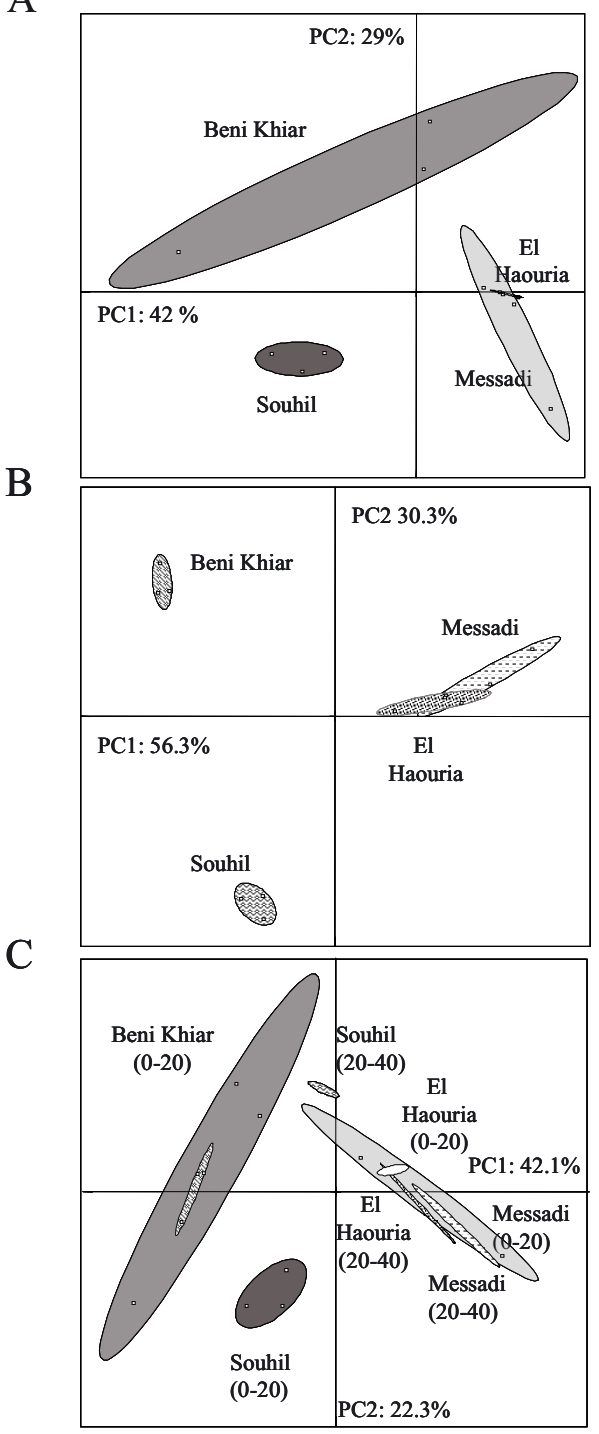

Figure 1. Principal component ( $\mathrm{PC} 1$ on $\mathrm{x}$-axis, $\mathrm{PC} 2$ on $\mathrm{y}$-axis) factorial maps generated from B-ARISA (Automated Ribosomal Intergenic Spacer Analysis) profiles obtained at depths of 0-20 cm (A), $20-40 \mathrm{~cm}(\mathrm{~B})$ and both depths together (C) at the different studied sites. This analysis shows the significant discrimination of bacterial community structure between the studied sites. Percentages of both axes represent the explained variability of the variables (genetic structure of community).

the observed modifications was positively correlated with the duration of irrigation. To date, several studies have demonstrated the impact of wastewater irrigation on the abundance of microbial communities, but our study is one of the first to highlight such an impact on the structure and composition of the indigenous communities. The observed modifications might partly be explained by the input of toxic metallic elements such as $\mathrm{Cu}, \mathrm{Ni}, \mathrm{Cd}$, etc., which may be accumulated by soils (see Sect. 2.2) depending on the duration of the irrigation management scheme. It is frequently reported in the literature
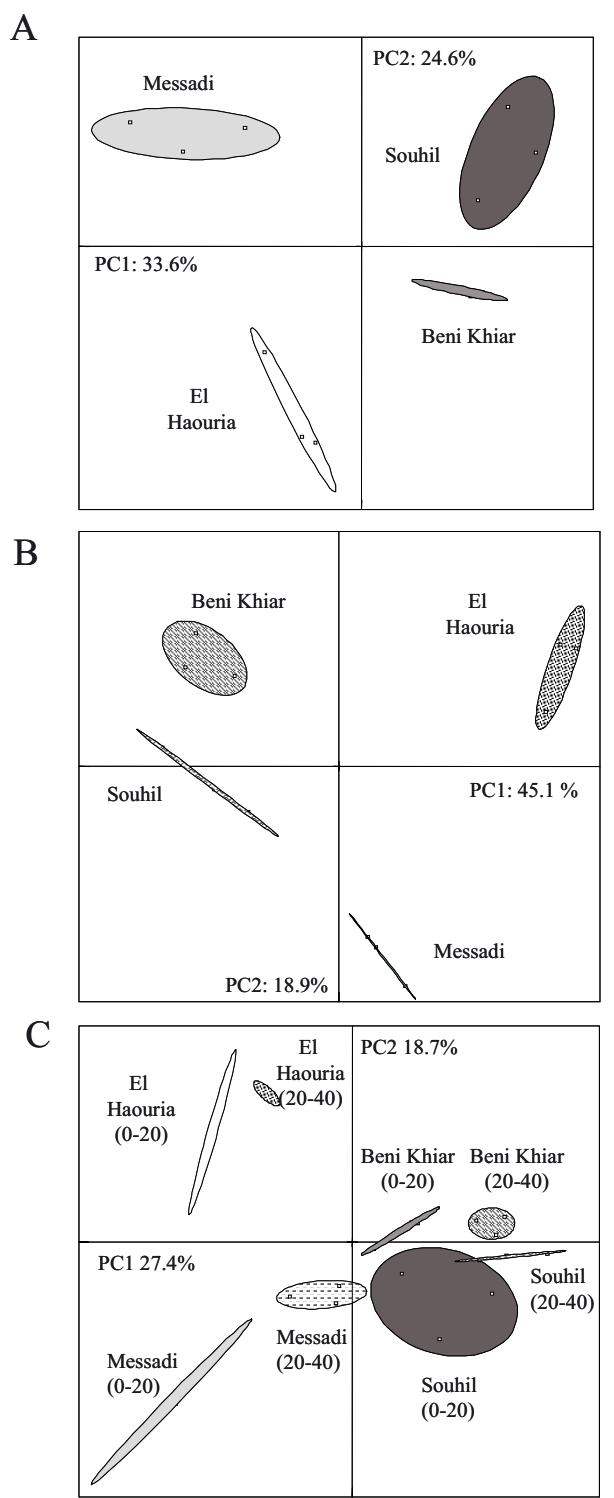

Figure 2. Principal component (PC1 on $\mathrm{x}$-axis, $\mathrm{PC} 2$ on $\mathrm{y}$-axis) factorial maps generated from F-ARISA (Automated Ribosomal Intergenic Spacer Analysis) profiles obtained at depths of 0-20 cm (A), 20-40 cm (B) and both depths together (C) at the different studied sites. This analysis shows the significant discrimination of fungal community structure between the studied sites. Percentages of both axes represent the explained variability of the variables (genetic structure of community).

that these metallic elements can induce significant modifications in bacterial and fungal genetic structure (Ranjard et al., 2006). On the other hand, wastewater can also modify microbial composition by providing nutrient resources for microorganisms through the input of organic compounds. Microorganisms are mainly heterotrophic and carbon-limited in soil and the observed differences between sites could be due to a lower availability of the carbon source in the sites recently subjected to irrigation compared with the higher soil carbon stock 
in sites irrigated for one or two decades (Tab. I). Similar hypotheses have been put forward for forest and agricultural soils in which the distinct composition of the microbial communities is probably due to the availability and quality of litter or to organic management practices (Lejon et al., 2005; Myers et al., 2001).

As regards the soil physicochemical characteristics listed in Tables I and II, no significant relationship was apparent between the contents of carbon and of metallic elements. The observed modifications of the microbial communities were therefore probably the complex resultant of the recurrent stimulation due to organic inputs and the deleterious effects of contamination with metallic elements, combined with the modifications of soil characteristics such as $\mathrm{pH}$.

A similar and significant discrimination between bacterial and fungal community structures was observed at $20-40 \mathrm{~cm}$ depth (Fig. 2B), indicating that the impact of irrigation with wastewater could be observed at a deeper level. More precisely, the data obtained at $0-20$ and $20-40 \mathrm{~cm}$ revealed a weak discrimination of the bacterial communities with depth (Fig. 2C) and a significant stratification of the fungal communities (Fig. 3C). The absence of stratification for the bacterial community might be partly explained by the soil's sandy texture, which would lead to weak accumulation of both organic matter and metallic elements in the topsoil due to the significance of mineralisation and leaching processes (Wang et al., 2003). However, such an observation is not demonstrated for El Haouria, maybe because of the short length of irrigation time (4 years), which may not be enough to induce significant modifications. A greater stratification with increased depth for the fungal, as compared with the bacterial community, is generally recorded in different types of ecosystems such as agricultural and forest soils (Lejon et al., 2005, 2007). In our study, the higher $\mathrm{pH}$ values and lower Corg contents observed at 20-40 cm depth might explain the observed stratification of the fungal communities (Tab. I) and would confirm the greater sensitivity of fungal communities to wastewater management. In addition, under tree cover the distinct fungal communities between soil layers could be attributed to differences in mycorrhizal associations and rooting distribution in depth.

Altogether, our results showed that the different wastewater management schemes led to different soil characteristics and different substrate availabilities, and were probably behind the significant changes observed in microbial abundance and genetic structure of the microbial communities. However, studies of different types of wastewaters and soils are needed before these results can be generalised, because changes in microbial community are also considerably influenced by soil type and certain agricultural practices. Investigations should also be conducted to accurately determine the influence of the observed changes in community composition on soil biological functioning, particularly in terms of fertility, crop productivity and human health in the context of sustainable development.

Acknowledgements: The authors would like to thank Virginie Nowak (UMR Microbiologie du Sol et de l'Environnement - INRA/Université de Bourgogne) for technical assistance. The present study is part of the "EC2CO" programme which is supported by the French Ministry of Research and INSU.

\section{REFERENCES}

Al-Lahham O., El Assi N.M., Fayyad M. (2003) Impact of treated wastewater irrigation on quality attributes and contamination of tomato fruit. Agr. Water Manage. 61, 51-62.

Alloway B.J. (1995) Heavy metals in soils, Chapman and Hall, London, UK.

Angelakis A.N., Marecos Do Monte M.H.F., Bontoux L., Asano T. (1999) The status of wastewater reuse practice in the Mediterranean Basin: need for guidelines, Water Res. 33, 2201-2217.

Berg M.P., Kniese J.P., Verhoef H.A. (1998) Dynamics and stratification of bacteria and fungi in the organic layers of a Scots pine forest soil, Biol Fert. Soils 26, 313-322.

Bronick C.J., Lal R. (2005) Soil structure and management: a review, Geoderma 124, 3-22.

Campos C. (1998) Indicatores de contamination fecal en la reutilization de agua residual regenerada en suelos, Tesis Doctoral, Universidad de Barcelona.

Candela L.S., Fabregat A., Josa J., Suriol N., Vigués D., Mas J. (2007) Assessment of soil and groundwater impacts by treated urban wastewater reuse. A case study: Application in a golf course (Girona, Spain), Sci. Total Environ. 374, 26-35.

Cohen S.A., Svrjcek T., Durborow D., Barnes L. (1999) Water quality impacts by golf courses, J. Environ. Qual. 28, 798-809.

Cooper R.C. (1991) Public-health concerns in wastewater reuse, Water Sci. Technol. 24, 55-65.

Crook J. (1991) Quality criteria for reclaimed water, Water Sci. Technol. 24, 109-121.

Day A.D., Rahman A., Katterman F.R., Ryan J.A. (1974) Effect of treated municipal wastewater and commercial fertilizer on growth, fiber, acid-soluble nucleotides, protein, and amino acid content in Wheat Hay, J. Environ. Qual. 3, 17-19.

de Boer W., Folman, L.B., Summerbell, R.C., Boddy L. (2005) Living in a fungal world: impact of fungi on soil bacterial niche development, FEMS Microbiol. Rev. 29, 795-811.

Dère C.I., Lamy A., Jaulin S., Cornnu S. (2006) Long term fate of exogenous metals in a sandy Luvisol subjected to intensive irrigation with raw wastewater, Environ. Pollut. 15, 1-10.

Doughton C.G. (2004) Non-regulated water contaminants: emerging research, Environ. Impact Asses. Rev. 24, 711-732.

Duxburry T., Bicknell B. (1983) Metal-tolerant bacterial populations from natural and metal polluted soils, Soil Biol. Biochem. 15, $243-250$.

Haas C. (1996) How to average microbial densities to characterize risk, Water Res. 30, 1036-1038.

Lawes S. (1993) Analysis of heavy metal-contaminated soil and anaerobically digested sewage sludge, B.Sc. Thesis, Department of Agricultural Chemistry and Soil Science, University of Sydney.

Lejon D.P.H., Chaussod R., Ranger J., Ranjard L. (2005) Microbial community structure and density under different tree species in an acid forest soil (Morvan, France), Microbial Ecol. 50, 614-625.

Lejon D.P.H., Sebastia J., Lamy I., Nowak V., Chaussod R., Ranjard L. (2007) Relationship between soil organic status and microbial density and genetic structure in two agricultural soils submitted to various organic managements, Microbial Ecol. 53, 650-653. 
Martinez-Beltran J. (1999) Irrigation with saline water: benefits and environmental impact, Agr. Water Manage. 40, 183-194.

Mazahreh M.N. (2003) Changes in soil fertility parameters in response to irrigation of forage crops with secondary treated wastewater, Commun. Soil Sci. Plan. 34, 1281-1294.

Myers R.T., Zak D.R., White D.C., Peacock A. (2001) Landscape-level patterns of microbial community composition and substrate use in upland forest ecosystems, Soil Sci. Soc. Am. J. 65, 359-367.

Palese A.M., Pasquale V., Celano G., Figliuolo G., Masi S., Xiloyannis Q. (2009) Irrigation of olive groves in Southern Italia treated municipal wastewater: Effects on microbiological quality of soil and fruits, Agr. Ecosys. Environ. 129, 43-51.

Ramirez-Fuentes E., Lucho-Constantino C., Escamilla-Silva E., Dendooven L. (2002) Characteristics, and carbon and nitrogen dynamics in soil irrigated with wastewater for different lengths of time, Bioresource Technol. 85, 179-187.

Ranjard L., Lejon D., Mougel C., Scherer L., Merdinoglu D., Chaussod R. (2003) Sampling strategy in molecular microbial ecology: influence of soil sample size on DNA Fingerprinting analysis of fungal and bacterial communities, Environ. Microbiol. 5, 1111-1120.

Ranjard L., Lignier L., Chaussod R. (2006) Cumulative effects of short term poly-metallic contaminations on soil bacterial community structure, Appl. Environ. Microb. 72, 1684-1687.

Ranjard L., Nazaret S., Gourbière F., Thioulouse J., Linet P., Richaume A. (1997) A soil microscale study to reveal the heterogeneity of $\mathrm{Hg}$ (II) impact on indigenous bacteria by quantification of adapted phenotypes and analysis of community DNA fingerprints, FEMS Microbiol. Ecol. 31, 107-115.

Ranjard L., Nowak V., Echairi A., Faloya V., Chaussod R. (2008) The dynamics of soil bacterial community structure in response to yearly repeated agricultural copper treatments, Res. Microbiol. 159, 251-254.

Ronen D. (1996) Monitoring chemical processes and transport phenomena in the water table region of phreatic aquifers- review of a study conducted under agricultural land irrigated with sewage effluents, in Candela L., Aureli A. (Eds.), IHP-UNESCO, IAMZ-CIHEAM and ETSCCPB-DIT-UPC, Agricultural threats to ground water quality, A workshop, 27-30 October 1996, Zaragoza, Spain, 1998, pp. $45-59$.

Schipper L.A., Williamson J.C., Kettles H.A., Speir T.W. (1996) Impact of land-applied tertiary-treated effluent on soil biochemical properties, J. Environ. Qual. 25, 1073-1077.

Shetty S. (2004) Treated wastewater use in Tunisia: Lessons Learned and the Road Ahead, The World Bank, Jakarta, Indonesia.

Siebe C. (1995) Nutrient inputs to soils and their uptake by alfalfa through long-term irrigation with untreated sewage effluent in Mexico, SoilUse-Manage, CAB International, Oxford, pp. 119-122.

Ternes T.M., Meisenheimer D., Mcdowell F., Sacher H., Brauch H., Haist-Gulde B. (2002) Removal of pharmaceuticals during drinking water treatment, Environ. Sci. Technol. 36, 3855-3863.

Thioulouse J., Chessel D., Dolédec S., Olivier J.M. (1997) ADE-4: a multivariate analysis and graphical display software, Stat. Comput. 7, $75-83$.

Toshinari S.K., Harumi Y., Kumiko M., Tosio M., Testsuya S. (1998) Estimation of leachability and persistence of pesticides at golf courses from point-source. Monitoring and model to predict pesticide leaching to groundwater, Environ. Sci. Technol. 32, 920-929.

Wang W.J., Dalal R.C., Moody P.W., Smith C.J. (2003) Relationships of soil respiration to microbial biomass, substrate availability and clay content, Soil Biol. Biochem. 35, 273-284.

Weber S.S., Khan S., Hollender J. (2006) Human risk assessment of organic contaminants in reclaimed wastewater used for irrigation, Desalination 187, 53-64.

WHO (1989) Health guidelines for the use of wastewater in agriculture and aquaculture: Report of a WHO Scientific Group, WHO Technical Report Series 778, World Health Organization, Geneva, Switzerland, p. 74. 